\title{
Economic profitability of crop rotation systems in the Caiuá sandstone area
}

\author{
Bruno Volsi' (iD) Ivan Bordin ${ }^{2}$ (D) Gabriel Eiji Higashi² ${ }^{2}$ Tiago Santos Telles ${ }^{2 *}$ \\ ${ }^{1}$ Programa de Pós-graduação em Agronomia, Universidade Estadual de Londrina (UEL), Londrina, PR, Brasil. \\ Instituto Agronômico do Paraná (IAPAR), 86047-902, Londrina, PR, Brasil. E-mail: telles@iapar.br. "Corresponding author.
}

ABSTRACT: Even in areas of predominance of Caiuá sandstone, with soils of low natural fertility that are highly susceptible to erosion and degradation processes, farmers have adopted systems with little diversification, because they believe that they provide a greater economic return. However, agricultural practices such as crop rotation can bring agronomic benefits in terms of conservation agriculture, in addition to economic gains, circumventing edaphoclimatic difficulties in the region. In this context, the objective of this study is to verify whether no-till crop rotation systems are economically profitable, in a Caiuá sandstone area in the northwest region of the Brazilian state of Paraná. To this end, an experiment was conducted in the municipality of Umuarama, state of Paraná, in the crop year 2014/15 to 2016/17. The experimental design used random blocks, with four treatments and four repetitions. The treatments consisted of four crop rotation systems, involving wheat, black oats, canola, safflower, rye, crambe, beans, maize, fodder radish, soybean, sorghum, lupin beans, buckwheat, and triticale cultivars. Crop yields, operating costs, income, and net farm income were assessed. From the results, it was reported that the highest income was obtained in the systems that adopted the largest number of winter and summer commercial crops. Only one treatment was profitable, that is, it had a positive net farm income. This scenario may be associated with the fragility of the region's soil, which having low fertility, requires a high investment in fertilization and liming to ensure adequate production.

Key words: cost analysis, agricultural production, agricultural economy, rural administration, conservation agriculture.

Rentabilidade econômica de sistemas de rotação de culturas em área de arenito Caiuá

RESUMO: Mesmo em áreas de predomínio do arenito Caiuá, com solos de baixa fertilidade natural e altamente susceptiveis a processos de erosão e degradação, agricultores têm adotado sistemas com baixa diversificação, por acreditarem que estes apresentam maior retorno econômico. No entanto, práticas agricolas como a rotação de culturas podem trazer benefícios agronômicos, relativos à agricultura conservacionista, além de ganhos econômicos, contornando dificuldades edafoclimáticas da região. Neste contexto, o objetivo deste estudo foi verificar se na região Noroeste do Paraná, em área de arenito Caiuá, sistemas de rotação de culturas sob plantio direto apresentam rentabilidade econômica. Para tanto, foi conduzido um experimento no município de Umuarama, estado do Paraná, entre anos agrícolas de 2014/15 a 2016/17. O delineamento experimental foi de blocos ao acaso, com quatro tratamentos e quatro repetições. Os tratamentos constituíram-se de quatro sistemas de rotações de culturas, que envolveram cultivares de trigo, aveia preta, canola, cártamo, centeio, crambe, feijão, milho, nabo forrageiro, soja, sorgo, tremoço, trigo mourisco e triticale. Foram avaliadas as produtividades das culturas, os custos variáveis, as receitas e as margens brutas. A partir dos resultados, verificou-se que as melhores receitas foram obtidas nos sistemas que adotaram o maior número de culturas comerciais de inverno e verão. Somente um tratamento apresentou rentabilidade, ou seja, margem bruta positiva. Este cenário pode estar associado à fragilidade do solo da região, que por serem de baixa fertilidade, demandam alto investimento com adubação e calagem, para garantir uma produção adequada.

Palavras-chave: análise de custo, produção agrícola, economia agrícola, administração rural, agricultura conservacionista.

\section{INTRODUCTION}

The choice of farmers for systems with little diversification is largely justified by the short-term economic return (MARCELO et al., 2012). However, these systems go against what is recommended from a technical-agronomic point of view and conservation agriculture (KASSAM et al., 2009; TELLES et al., 2019). This is because the adoption of these cultivation systems may lead to several obstacles in the sustainability of agricultural production, such as the development of pests, diseases, weeds, and nematoids, and may result in loss of soil quality, compromising its productive capacity (VEZZANI; MIELNICZUK, 2009). Thus, systems based on specialization in a few crops 
are becoming less efficient and sustainable, due to stagnated production and increased production costs (TILMAN et al., 2019).

Sustainability in agriculture remains relevant in the Brazilian agricultural scene, with producers increasingly searching for systems aiming to mitigate the environmental impact of extractive agriculture and food security of production (COSTA, 2010). Thus, crop rotation stands out as a sustainable agricultural practice, because when carried out continuously, it leads to structural and physicochemical soil improvements (CASTRO et al., 2011; BORTOLUZZI et al., 2010).

The economy of the Umuarama region in the northwest of the Brazilian state of Paraná is directly linked to agriculture. One of the characteristics of the region is the predominance of sandy soils, derived from Caiuá sandstone, which have low natural fertility and are highly susceptible to erosion and degradation processes. One of the highest mean temperatures in Paraná is also recorded there, with a significant annual thermal amplitude (SILVA et al., 2015). In addition, according to data obtained from Municipal Agricultural Production (PAM) from the Brazilian Institute of Geography and Statistics (IBGE), in 2017, the cultivation of soybean (38\%), sugar cane $(23 \%)$, and cassava $(8 \%)$ was predominant in areas occupied with temporary crops. In other words, these crops occupied about $70 \%$ of the region's agricultural area, denoting low diversity. In general, these data confirmed the occurrence of poorly diversified systems, a fact that opposes the model recommended by conservation agriculture, namely, crop rotation systems (CHAVAS, 2008).

Crop rotation increases the levels of organic carbon, nitrogen, and the overall amount of nutrients readily available to plants, contributing to the preservation of soil quality (LISBOA et al., 2012). However, these benefits depend on the species and crop sequences adopted by the producer (FONSECA t al., 2007; PERIN et al., 2004). Therefore, commercial plants are preferentially recommended and, whenever possible, associated with regionally adapted roofing plant species producing large quantities of dry matter and rapidly developing (MACHADO; ASSIS, 2010). The sowing of grasses and legumes, whether grown alone or in association, can also be considered, as they contribute to a greater balance of this system as a whole. Furthermore, rotation is an alternative to grain producers, because other crops can also be used in the production system, both agronomically benefiting the rotation system and generating economic gains (FONTANELI et al., 2000).
Although, the technical-agronomic benefits of no-till crop rotation systems are well described in literature (MALÉZIEUX et al., 2009; BERTOL, 2004; MCGILL et al., 1984; VIEIRA; MUZILLI, 1984), studies on the economic advantages resulting from their adoption are incipient (AL-KAISI et al., 2016; AL-KAISI et al., 2015; GRASSINI et al., 2014; GENTRY et al, 2012), particularly in the Brazilian reality (FUENTES-LLANILLO et al., 2018; LEAL et al., 2005; SANTOS et al., 1999) and especially for the region where Caiuá sandstone is predominant. The low adoption of conservationist production systems may be because farmers do not see an economic return with crop rotation, especially in the short term. In this context, the hypothesis is that more diversified crop rotation systems may be more profitable than less diversified systems.

Bearing this in mind, the objective of this study was to verify whether no-till crop rotation systems are economically profitable in a Caiuá sandstone area in the northwest region of Paraná.

\section{MATERIALS AND METHODS}

The experimental area is located in the municipality of Umuarama, State of Paraná, Brazil, and conducted at the Agronomic Institute of Paraná. It is located geographically at $23^{\circ} 44^{\prime}$ South and $53^{\circ}$ $17^{\prime}$ 'West, at an altitude of $480 \mathrm{~m}$. The soil is classified as a dystrophic red oxisol, with flat or slightly undulating relief (SANTOS et al., 2013) and sandy and medium texture, associated with the sandstones of the Caiuá Formation (CUNHA et al., 2012).

According to the Köppen classification, the region has a climate of Cfa type, humid subtropical, with an annual average temperature of $22.2{ }^{\circ} \mathrm{C}$ and annual average rainfall of approximately $1544 \mathrm{~mm}$. As for the climatic conditions of crop years 2014/15, $2015 / 16$, and $2016 / 17$, the graph of maximum and minimum daily temperature and the 10-day water balance of the experiment is presented (Figure 1), using the Tornthwaite and Mather method according to the spreadsheets by ROLIM et al. (1998).

The experimental design was in random blocks, consisting of four blocks and four treatments. Each treatment relates to a different production system (Table 1), with each plot measuring $10 \mathrm{~m} \times$ $30 \mathrm{~m}\left(300 \mathrm{~m}^{2}\right)$, spaced $10 \mathrm{~m}$ from each other to leave room to maneuver machines. In the 11 years before the experiment was installed, the area had been planted in a no-till system.

Each production system had a distinct purpose. Treatment I aimed to obtain the maximum 


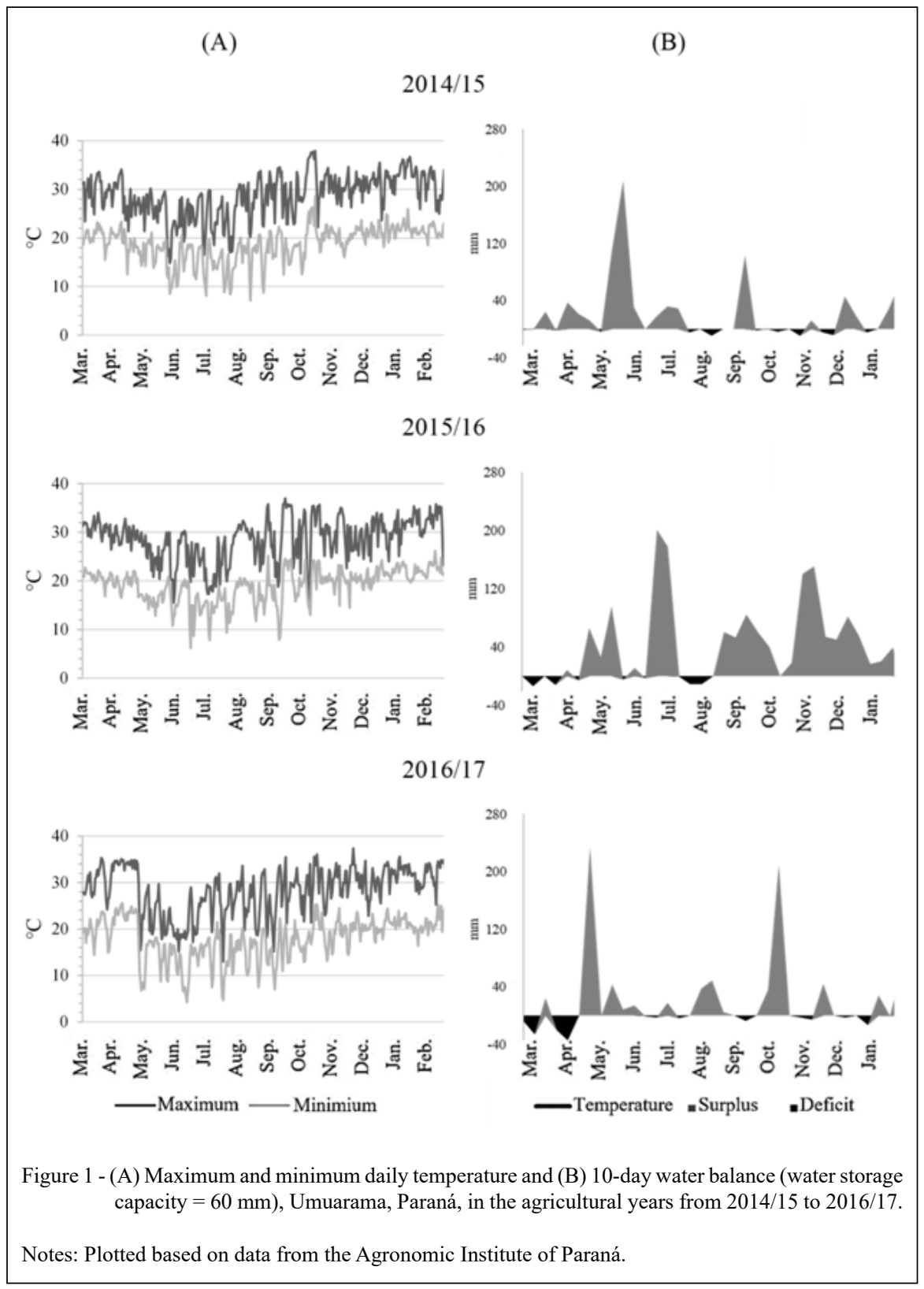

amount of straw, giving way in winter to black oats, fodder radish, and rye crops. Treatment II was a little exploited system but had commercial potential. Treatment III aimed to produce crops linked to agroenergy, such as canola, crambe, and safflower. Treatment IV aimed to have the greatest diversification of cultures. From table 2, we can observe the genotypes of the different species used in each production system and their respective sowing dates. The soybean seeds used were of the BMX Potência cultivar in the 2014/2015 and 2015/2016 crops, and of the Ícone cultivar in the 2016/2017 harvest. For the cultivation of maize, the 30A95 cultivar was used. Winter crops were sown between March and May and summer crops in October.

For the economic analysis, all services and inputs used in each production system were considered. For the calculation of the cost of machinery operations, such as machinery rental and labor, a medium-sized rural property was assumed, that is, a rural property with an area between 4 and 15 "fiscal modules", one "fiscal module" in the Umuarama 
Table 1 - Crop rotation systems conducted in Umuarama in the crop years 2014/15, 2015/16, and 2016/17.

\begin{tabular}{lcccccc}
\hline Treatments & & & & & & \\
& Winter & Summer & Winter & Summer & Winter & Summer \\
I & BO+R & S & BO/FD & SG & BO+R & S \\
II & TRT & M & SG & S & TRT & S \\
III & CR & SG & CNL & SF & S \\
IV & LB & M+B & EB & M & S \\
\hline
\end{tabular}

Notes: W: wheat. S: soybean. BO: black oats. M: maize. CNL: canola. LB: lupin beans. EB: edible beans. FD: fodder radish. TRT: triticale. R: rye. CR: crambe. SF: safflower.

region of the State of Paraná varies between 18 and 24 hectares in area a range. That represents the vast majority of rural properties reported in the Umuarama region, Northwestern Paraná.

In the analysis of operational costs, all of those related to production were considered, that is, expenditure from soil preparation to harvest, following the methodology by KAY et al. (2014). To compose the costs of sowing, spraying, and harvesting operations, the technical coefficients of the Experimental Station were used. The values for the machinery operating and for the inputs used were all extrapolated per hectare. To obtain these costs, a survey on the average values paid by producers in August 2014, 2015, and 2016 was undertaken based on information obtained from at least three cooperatives or companies in the Umuarama region.

Net farm income was calculated by subtracting each treatment's operating cost from its income. Revenue calculation was based on the average production obtained in each production system, multiplied by its respective selling price at the time of harvest. Productivity, in turn, was obtained from weighing the harvested grains coming from the useful area of the plots and extrapolating the values to $\mathrm{kgha}^{-1}$, corrected to $13 \%$ humidity (wet weight).

All economic indicators were corrected to June 2019 values using the Extended National Consumer Price Index (IPCA), the official inflation index in Brazil. Values were converted to US dollars based on the current exchange rate.

\section{RESULTS AND DISCUSSION}

Table 3 presents the productivity results for each crop rotation system in the three crop years of the experiment. It was found that overall, soybean productivity was below the average of the state of

Table 2 - Genotypes of different species used in crop rotations systems with their respective sowing dates, conducted in Umuarama in the crop years 2014/15, 2015/16, and 2016/17

\begin{tabular}{|c|c|c|c|c|c|c|}
\hline \multirow[t]{2}{*}{$\mathrm{T}$} & \multicolumn{2}{|c|}{-------------------------2014/15---------------------- } & \multicolumn{2}{|c|}{-----------------------2015/16------------------- } & \multicolumn{2}{|c|}{ 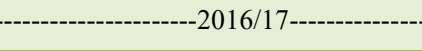 } \\
\hline & Winter & Summer & Winter & Summer & Winter & Summer \\
\hline I & $\begin{array}{c}\text { IPR } 61+\text { IPR } 89 \\
(10 / 04 / 14)^{1}\end{array}$ & $\begin{array}{c}\text { BMX Potência } \\
(06 / 10 / 14)\end{array}$ & $\begin{array}{c}\text { IPR } 61 / \text { IPR } 116 \\
(09 / 04 / 15)\end{array}$ & $\begin{array}{c}\text { BM } 737 \\
(16 / 10 / 15)\end{array}$ & $\begin{array}{c}\text { IPR } 61+\text { IPR } 89 \\
(05 / 05 / 16)\end{array}$ & $\begin{array}{c}\text { Ícone } \\
(05 / 10 / 16)\end{array}$ \\
\hline II & $\begin{array}{c}\text { IPR } 111 \\
(11 / 04 / 14)\end{array}$ & $\begin{array}{c}30 \mathrm{~A} 95 \\
(03 / 10 / 14)\end{array}$ & $\begin{array}{c}\text { BM } 737 \\
(07 / 04 / 15)\end{array}$ & $\begin{array}{c}\text { BMX Potência } \\
(05 / 10 / 15)\end{array}$ & $\begin{array}{c}\text { IPR } 111 \\
(29 / 04 / 16)\end{array}$ & $\begin{array}{c}\text { Ícone } \\
(05 / 10 / 16)\end{array}$ \\
\hline III & $\begin{array}{l}\text { FMS Brilhante } \\
\text { (11/04/14) }\end{array}$ & $\begin{array}{c}\text { BM } 737 \\
(23 / 10 / 14)\end{array}$ & $\begin{array}{l}\text { CPI 0801* } \\
(06 / 04 / 15)\end{array}$ & $\begin{array}{c}30 \mathrm{~A} 95 \\
(05 / 10 / 15)\end{array}$ & $\begin{array}{c}\text { CIPL 0407* } \\
(28 / 03 / 16)\end{array}$ & $\begin{array}{c}\text { Ícone } \\
(05 / 10 / 16)\end{array}$ \\
\hline IV & $\begin{array}{l}\text { IAPAR } 24 \\
(10 / 04 / 14)\end{array}$ & $\begin{array}{c}\text { 30A95+ } \\
\text { Brachiariaruziziensis } \\
(03 / 10 / 14)\end{array}$ & $\begin{array}{c}\text { IPR Campos } \\
\text { Gerais }(06 / 04 / 15)\end{array}$ & $\begin{array}{c}30 \mathrm{~A} 95 \\
(05 / 10 / 15)\end{array}$ & $\begin{array}{c}\text { IPR 91* } \\
(29 / 03 / 16)\end{array}$ & $\begin{array}{c}\text { Ícone } \\
(05 / 10 / 16)\end{array}$ \\
\hline
\end{tabular}

Notes: T: Treatments. ${ }^{*}$ Experimental cultivar. ${ }^{1}$ The information in parentheses refers to the sowing date of each crop. ${ }^{+}$represents cultures carried out in association. ' represents individual crops, one subsequent to another. 
Table 3 - Productivity $\left(\mathrm{kg} \mathrm{ha}^{-1}\right)$ of grains in production systems for the 2014/2015, 2015/2016 and 2016/2017 crops in Umuarama, Paraná.

\begin{tabular}{|c|c|c|c|c|c|c|}
\hline \multirow[b]{2}{*}{ Treatments } & \multicolumn{2}{|c|}{-----------------2014/15-------------- } & \multicolumn{2}{|c|}{----------------2015/16-------------. } & \multicolumn{2}{|c|}{---------------2016/17---------- } \\
\hline & Winter & Summer & Winter & Summer & Winter & Summer \\
\hline \multirow{2}{*}{ I } & $\mathrm{BO}+\mathrm{R}$ & $\mathrm{S}$ & $\mathrm{BO} / \mathrm{FD}$ & SG & $\mathrm{BO}+\mathrm{E}$ & $\mathrm{S}$ \\
\hline & - & 3.009 & - & 5.648 & - & 3.285 \\
\hline \multirow{2}{*}{ II } & TRT & M & SG & S & TRT & $\mathrm{S}$ \\
\hline & 1.742 & 8.324 & 3.033 & 3.019 & 1.580 & 3.406 \\
\hline \multirow{2}{*}{ III } & $\mathrm{CR}$ & SG & $\mathrm{CNL}$ & M & SF & $\mathrm{S}$ \\
\hline & 1.627 & 5.004 & 1.196 & 7.926 & 991 & 3.436 \\
\hline \multirow{2}{*}{ IV } & LB & $\mathrm{M}+\mathrm{B}$ & EB & M & BW & $\mathrm{S}$ \\
\hline & - & 8.014 & 1.940 & 8.056 & 1.934 & 3.780 \\
\hline
\end{tabular}

Notes:W: wheat. S: soybean. BO: black oats. M: maize. CNL: canola. LB: lupin beans. EB: edible beans. FD: fodder radish. TRT: triticale. R: rye. CR: crambe. SF: safflower. SG: sorghum. BW: buckwheat. B: brachiaria. “-": there was no harvest.

Paraná, which according to the National Supply Company (CONAB, 2018), was 3,741 $\mathrm{kgha}^{-1}$ for the 2016/17 crop year.

These low yields are mainly due to the morphological characteristics of the soil derived from the Caiuá sandstone formation, which is highly susceptible to weathering (BARBOSA et al. 2013). The water deficit may also be responsible for low yields, because it has a negative impact on plant growth and development, especially when it occurs in the period of flowering and grain filling (GAVA et al., 2015; TAVARES et al., 2013; SANTOS et al., 2012; FIOREZE et al., 2011). Water deficit was observed in the summer of 2014/15, between October and January; in the winter of 2015/16, in March and August; and in the winter and summer of 2016/17, between March and April and between September and January (Figure 1).

High and low temperatures also contributed to the lower growth of plants. The main crops affected were safflower, triticale, buckwheat, sorghum, and canola. In the case of buckwheat, it was the low temperature observed in the winter of $2015 / 17$, which reached $5{ }^{\circ} \mathrm{C}$. The damage caused by frost starts with an air temperature below $3{ }^{\circ} \mathrm{C}$, since there is a difference of $2.1{ }^{\circ} \mathrm{C}$ to $4.8^{\circ} \mathrm{C}$ between the air temperature under the cover and the grass (SILVA; SENTELHAS, 2001)

Regarding soybean, in the summer of 2016/17, only Treatment IV showed soybean productivity $\left(3,780 \mathrm{kgha}^{-1}\right)$ slightly above the state average $\left(3,741 \mathrm{kgha}^{-1}\right)$. This treatment adopted a rotation system with the greatest crop diversification. The worst performance was obtained in Treatment I $\left(3,285 \mathrm{kgha}^{-1}\right)$. In the case of maize cultivation, only Treatment II in the summer of 2014/15 and Treatment IV in the summer of 2015/16 presented productivity higher than the average of Paraná of $8,025 \mathrm{kgha}^{-1}$ (CONAB, 2018). The best performance for maize was observed in Treatment II $\left(8,324 \mathrm{kgha}^{-1}\right)$, in which maize was grown shortly after the triticale harvest, while the lowest productivity was in Treatment III in the summer of $2015 / 16\left(7,926 \mathrm{kgha}^{-1}\right)$, shortly after canola cultivation. Crops such as safflower, crambe, and especially triticale, which have productive potential, tolerance to soil acidity, and good cycling and weed suppression capabilities (BRANCALIÃO et al., 2015), presented results below those reported in other studies. However, it is important to emphasize that the benefits of rotation can be significant, since the more diversified systems presented the best results, mainly due to the physical improvements that may occur in the soil, allowing the crop to develop properly and resulting in higher productivity in the following crops (FONSECA et al., 2007).

Table 4 presents the income, operating costs, and net farm income per hectare for each crop rotation system for the three crop years of the experiment. From the income data, it was reported that Treatment I, whose winter crops were not marketed, presented the lowest result. Thus, the highest income occurred in Treatment IV (US\$ $4,993.07)$, followed by treatments II (US\$ 3,818.11), III (US\$ 3,710.87), and I (US\$ 2,681.20). Regarding operating costs, the highest accumulated expenditure was observed in Treatment II (US\$ 4,617.84), followed by IV (US\$ 4,292.86), III (US\$ 4,013.13), and I (US\$ 3,331.88). On average, the cost of inputs 
Table 4 - Income. operating costs, and net farm income (US\$ ha ${ }^{-1}$ ) of production systems for the 2014/15, 2015/16 and 2016/17 cropsin Umuarama, Paraná.

\begin{tabular}{|c|c|c|c|c|c|c|c|c|c|}
\hline & \multicolumn{2}{|c|}{$2014 / 15$} & \multicolumn{2}{|c|}{$2015 / 16$} & \multicolumn{2}{|c|}{$2016 / 17$} & \multicolumn{2}{|c|}{ Average } & \multirow[t]{2}{*}{ Accumulated } \\
\hline & Winter & Summer & Winter & Sumer & Winter & Summer & Winter & Summer & \\
\hline Treatment I & $\mathrm{BO}+\mathrm{R}$ & S & $\mathrm{BO} / \mathrm{FD}$ & SG & $\mathrm{BO}+\mathrm{R}$ & S & & & \\
\hline Income & - & 967.04 & - & 736.35 & - & 977.82 & - & 893.73 & $2,681.20$ \\
\hline Operating costs & 212.91 & $1,038.68$ & 310.69 & 683.42 & 271.45 & 814.72 & 265.02 & 845.61 & $3,331.88$ \\
\hline Inputs & 82.03 & 557.37 & 136.56 & 325.92 & 148.23 & 461.92 & 122.28 & 448.40 & $1,712.04$ \\
\hline Seeds & 40.77 & 66.82 & 46.48 & 49.74 & 29.55 & 153.75 & 38.93 & 90.11 & 387.11 \\
\hline Fertilizer & - & 245.23 & - & 220.04 & - & 88.86 & - & 184.71 & 554.12 \\
\hline Herbicides & 34.11 & 80.01 & 83.38 & 56.15 & 118.68 & 87.34 & 78.72 & 74.50 & 459.67 \\
\hline Insecticides & - & 95.49 & 6.71 & - & - & 42.03 & 2.24 & 45.84 & 144.23 \\
\hline Fungicides & 7.15 & 60.33 & - & - & - & 89.93 & 2.39 & 50.09 & 157.42 \\
\hline Machinery operating & 111.01 & 340.52 & 134.42 & 236.65 & 88.49 & 205.70 & 111.30 & 260.96 & $1,116.79$ \\
\hline Other costs & 19.87 & 140.80 & 39.71 & 120.85 & 34.74 & 147.10 & 31.44 & 136.25 & 503.06 \\
\hline Net farm income & -212.91 & -71.64 & -310.69 & 52.92 & -271.45 & 163.09 & -265.02 & 48.13 & -650.68 \\
\hline Treatment II & TRT & M & SG & $\mathrm{S}$ & TRT & S & & & \\
\hline Income & 234.16 & 944.16 & 413.31 & $1,043.73$ & 168.86 & $1,013.89$ & 272.11 & $1,000.60$ & $3,818.11$ \\
\hline Operating costs & 492.55 & 912.36 & 708.36 & 911.63 & 774.03 & 818.90 & 658.31 & 880.96 & $4,617.84$ \\
\hline Inputs & 281.79 & 548.21 & 367.12 & 463.57 & 508.03 & 461.92 & 385.64 & 491.23 & $2,630.64$ \\
\hline Seeds & 50.92 & 111.17 & 49.74 & 47.00 & 81.01 & 153.75 & 60.56 & 103.98 & 493.59 \\
\hline Fertilizers & 172.55 & 312.32 & 190.82 & 158.36 & 181.70 & 88.86 & 181.69 & 186.51 & $1,104.60$ \\
\hline Herbicides & 35.42 & 124.72 & 98.07 & 73.36 & 72.60 & 89.02 & 68.70 & 95.70 & 493.20 \\
\hline Insecticides & - & - & 28.49 & 102.41 & - & 42.03 & 9.50 & 48.15 & 172.94 \\
\hline Fungicides & 22.90 & - & 0.00 & 55.56 & 172.72 & 88.25 & 65.21 & 47.94 & 339.44 \\
\hline Machinery operating & 155.05 & 235.74 & 233.42 & 284.25 & 160.78 & 207.73 & 183.08 & 242.57 & $1,276.96$ \\
\hline Others costs & 55.71 & 128.40 & 107.83 & 163.81 & 105.23 & 149.26 & 89.59 & 147.16 & 710.23 \\
\hline Net farm income & -258.39 & 31.80 & -295.05 & 132.10 & -605.18 & 194.99 & -386.21 & 119.63 & -799.73 \\
\hline Treatment III & CR & SG & CNL & M & SF & $\mathrm{S}$ & & & \\
\hline Income & 244.14 & 459.62 & 404.27 & $1,291.72$ & 288.29 & $1,022.82$ & 312.24 & 924.72 & $3,710.87$ \\
\hline Operating costs & 458.42 & 760.42 & 607.04 & 922.82 & 444.49 & 819.94 & 503.32 & 834.39 & $4,013.13$ \\
\hline Inputs & 244.63 & 444.90 & 302.01 & 469.25 & 223.23 & 461.92 & 256.62 & 458.69 & $2,145.95$ \\
\hline Seeds & 34.06 & 54.49 & 23.12 & 121.05 & 11.82 & 153.75 & 23.00 & 109.77 & 398.30 \\
\hline Fertilizer & 155.31 & 270.09 & 182.17 & 220.04 & 140.06 & 88.86 & 159.18 & 193.00 & $1,056.52$ \\
\hline Herbicides & 41.45 & 80.74 & 84.88 & 118.78 & 71.35 & 89.02 & 65.89 & 96.18 & 486.21 \\
\hline Insecticides & 13.82 & 39.59 & 11.84 & 9.38 & - & 42.03 & 8.55 & 30.33 & 116.66 \\
\hline Fungicides & - & - & - & - & - & 88.25 & - & 29.42 & 88.25 \\
\hline Machinery operating & 160.64 & 224.60 & 210.18 & 276.75 & 153.48 & 208.23 & 174.77 & 236.52 & $1,233.88$ \\
\hline Others costs & 53.14 & 90.91 & 94.86 & 176.82 & 67.78 & 149.79 & 71.93 & 139.17 & 633.30 \\
\hline Net farm income & -214.27 & -300.80 & -202.77 & 368.90 & -156.20 & 202.88 & -191.08 & 90.33 & -302.26 \\
\hline Treatment IV & LB & $\mathrm{M}+\mathrm{B}$ & EB & M & BW & $\mathrm{S}$ & & & \\
\hline Income & - & 909.04 & $1,274.10$ & $1,312.94$ & 371.83 & $1,125.16$ & 822.96 & $1,115.71$ & $4,993.07$ \\
\hline Operating costs & 150.53 & 878.20 & $1,056.34$ & 878.30 & 497.69 & 831.80 & 568.19 & 862.77 & $4,292.86$ \\
\hline Inputs & 55.42 & 536.64 & 590.18 & 469.25 & 269.83 & 461.92 & 305.14 & 489.27 & $2,383.24$ \\
\hline Seeds & 28.27 & 134.02 & 167.01 & 121.05 & 60.28 & 153.75 & 85.19 & 136.28 & 664.39 \\
\hline Fertilizer & 0.00 & 312.32 & 197.25 & 220.04 & 140.06 & 88.86 & 112.44 & 207.07 & 958.53 \\
\hline Herbicides & 27.15 & 90.30 & 67.67 & 118.78 & 69.49 & 89.02 & 54.77 & 99.37 & 462.41 \\
\hline Insecticides & - & - & 11.84 & 9.38 & - & 42.03 & 3.95 & 17.14 & 63.25 \\
\hline Fungicides & - & - & 146.41 & - & - & 88.25 & 48.80 & 29.42 & 234.67 \\
\hline Machinery operating & 80.81 & 217.92 & 277.05 & 236.81 & 155.90 & 213.96 & 171.25 & 222.90 & $1,182.45$ \\
\hline Other costs & 14.30 & 123.64 & 189.12 & 172.24 & 71.96 & 155.92 & 91.79 & 150.60 & 727.18 \\
\hline Net farm income & -150.53 & 30.84 & 217.75 & 434.64 & -125.86 & 293.36 & -19.55 & 252.95 & 700.20 \\
\hline
\end{tabular}

Notes: TW: wheat. S: soybean. BO: black oats. M: maize. CNL: canola. LB: lupin beans. EB: edible beans. FD: fodder radish. TRT: triticale. R: rye. CR: crambe. SF: safflower. SG: sorghum. BW: buckwheat. B: brachiaria. Monetary values corrected by the Extended National Consumer Price Index (IPCA), to June 2019. 
accounted for approximately 54\% of production costs, machinery operational costs for around $30 \%$, and other costs for around $15.8 \%$. It is worth noting that machinery operating was accounted for as outsourced services, which may have resulted in higher expenses with this item; and consequently in increase in production costs.

Quantification and analysis of the variables that make up production costs and revenues are of utmost importance for the rural producer's decision-making. However, this analysis requires a certain amount of caution, since higher costs do not necessarily mean lower profits, and conversely, lower costs do not necessarily mean higher profits. Investments in farming, especially in technologies and inputs, such as genetically modified seeds, may, on one hand, generate higher production costs, but on the other hand, generate higher revenue. This is because these investments, expressed in production costs, can bring improvement in plant development, increasing productivity; and consequently, the producer's income (ARTUZO et al., 2018).

Regarding the net farm income, a profitability indicator of production systems, the only positive result was observed in Treatment IV (US\$ 700.20), while the others generated losses: III (US\$ -302.26), I (US\$ -650.68), and II (US\$ -799.73). Treatment IV stood out for having presented good soybean productivity in the summer of 2016/17 and for the high market value of maize and beans in the 2015/16 agricultural year, resulting in the highest accumulated revenue. Thus, even with high variable production costs, Treatment IV obtained the highest revenue. This result shows that more diversified production systems are more profitable. The benefits of this more diverse system of production are also expressed in the scope economy (reduction of the cost per unit area due to the production of multiple crops). In the composition of this rotation system's costs, the expenditure on inputs in relative terms was $55.5 \%$. Among input costs, those destined to acquire highertechnology seeds stand out, representing $15.5 \%$ of the total cost - a value higher than those observed for the same component in the other treatments evaluated in this study. However, the use of higher-technology seeds, considered an investment, was converted into reduction in spending on fertilizers, agrochemicals (such as herbicides, insecticides, and fungicides), and machinery operating costs. With the reduced use of fertilizers, agrochemicals, and fuel, this agricultural production system also becomes more sustainable.

The average revenue was US\$ 822.96 for winter crops and US\$1,115.71 for summer crops.
The average variable cost was US\$ 568.19 for winter crops and US\$ 862.77 for summer crops. The crop with the highest production costs was Carioca beans, which in the winter of $2015 / 16$ cost US\$ $1,056.34$ to produce, mainly due to high expenditure on inputs. Overall, crop rotation systems, planned with a wide diversification of commercial plants, as was the case of this treatment, were able to present more profitable results compared with those with fewer commercial crops, in accordance with what was reported in the municipality of Passo Fundo, in the Brazilian state of Rio Grande do Sul (SANTOS et al., 2004), in the Midwest region of the United States (GOPLEN et al. 2018), and in Chile (GONZÁLEZ et al., 2013).

In Treatment III, a production system in which winter crops with low production costs were adopted, such as crambe, canola, and safflower, it was not possible to obtain profitable results, even though all winter and summer crops were commercialized. The average revenue was US\$ 312.24 for winter crops and US\$ 924.72 for summer crops. The average variable cost was US\$ 503.32 for winter crops and US\$ 834.39 for summer crops. Only maize and soybean crops showed a positive net farm income. The maize grown in the summer of 2015/16 stood out as more profitable due to the high market price during that harvest period. Soybean stood out for its productivity, which was close to the state average. Sorghum grown in the summer of 2014/15, due to its high production cost, had the worst gross-margin result. Overall, fertilizers were the input with the greatest participation in operating costs, and in the case of sorghum, it represented about $60 \%$ of the expenditure on inputs. Regarding the low revenue received from the sale of winter crops, especially crambe and canola, none of them showed a positive net farm income.

In Treatment I, the associations of noncommercial crops with all winter crops were the main contributor to the negative profitability result. Even though this treatment comprised different winter crops with low production costs, revenue acquired only from the sale of summer crops was not sufficient to cover all expenses. This system showed the lowest operating costs, averaging US\$ 265.02 for winter crops and US\$ 845.61 for summer crops. Since winter crops were not commercialized, the phytosanitary management adopted proved to be less rigorous, requiring a lower amount of inputs for the development of the crops and thus reducing spending. As in winter species were cultivated only for plant cover in this system, the execution of the experiment for three crop years may not be sufficient to obtain the 
expected results, especially regarding productivity gains (NUNES et al., 2006). Thus, even with the system showing a small revenue in this first crop rotation cycle, in the long term, the production of chaff can positively influence the profitability of successor crops (VALICHESKI et al., 2012; LEAL et al., 2005), since the plant cover contributed positively in several factors, such as weed suppression (KOOCHEKI et al., 2009) and reduced soil compaction (DEBIASI et al., 2010).

Treatment II was the least profitable, even though all winter and summer harvests were marketed and its revenue was the second highest. The negative result was mainly due to the high production cost of this treatment's crops. The highest operating costs were verified in this system, at US\$ 658.31 for winter crops and US\$ 880.96 for summer crops on average. Triticale had the highest production costs because of phytosanitary problems in the winter of 2016/17, leading to an about 7.5 times greater expenditure on fungicides compared with that for the winter of 2014/15. Due to the high costs in winter crops, there was loss of profitability in the production system, these crops usually generate a lower income than summer crops. It is worth noting that no winter culture managed to obtain a positive net farm income. In addition, the low market prices of both triticale and sorghum compromised this system's income. Thus, information about production costs and profitability is of paramount importance for producers, since an optimal combination of resources can help in choosing the most appropriate production system to their rural producer reality (GERLACH et al., 2013).

Since many producers have the possibility of storing the grain in silos in Southern Brazil, especially in cooperatives, the marketing system has become different from that in the rest of the country. This is because in the first year after the harvest of soybeans and maize, there are no administrative costs with storage, allowing a decision on when to sell stored products, with greater caution on the part of producers. Considering that soybean and maize can be sold at the peak prices recorded in each quarter over the 12 months after harvest, the results could show a differentiated trend for better or worse, considering that current prices at the time of the sale may be higher or lower than at the time of the harvest.

Figure 2 shows the evolution of the prices of $60 \mathrm{~kg}$ sacks (in US\$) of soybean and maize from July 2014 to May 2018. Results indicate that, even if soybean and maize are sold at peak prices, the results related to the economic profitability of the production systems analyzed in this study would not be altered. Only Treatment IV would still have a positive net farm income. From these findings, it is evident that the market conditions the farmer's profitability and may influence the result of the analysis, both positively and negatively, according to daily variations in the market prices of grains (LEHMANNA et al., 2013).

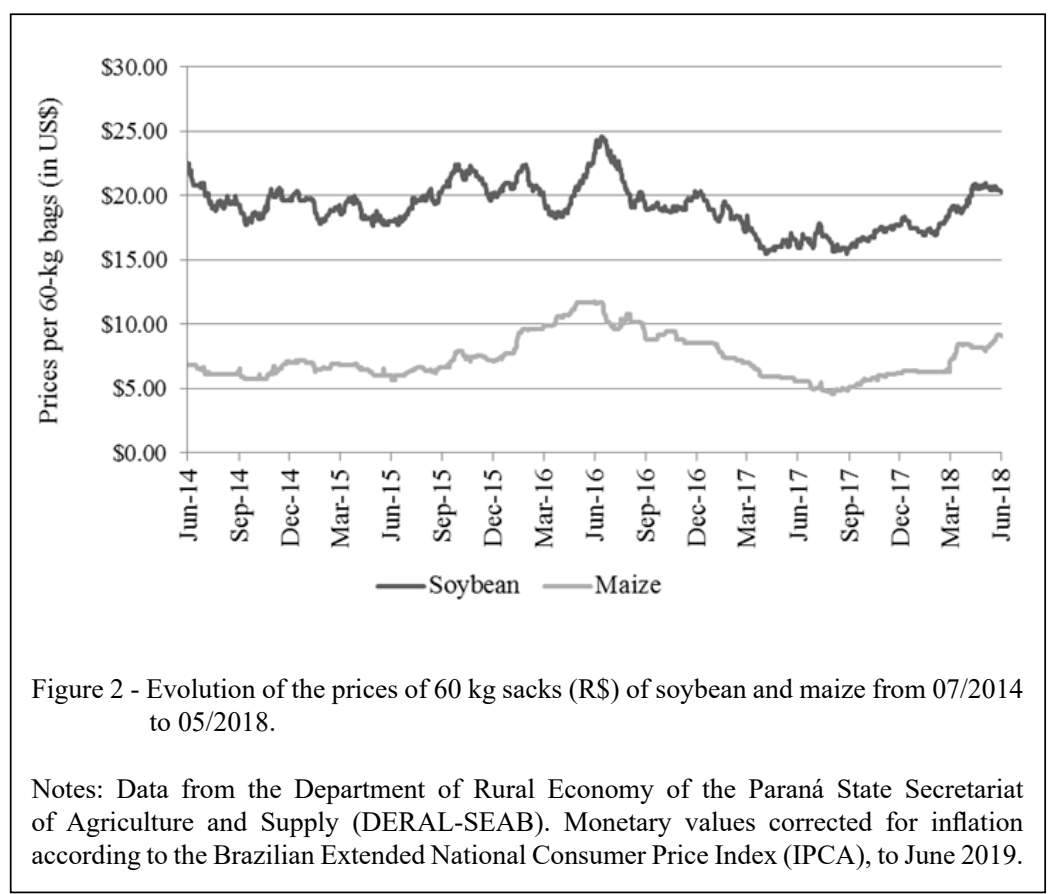

Ciência Rural, v.50, n.2, 2020. 
However, for the cycle from $2014 / 15$ to $2016 / 17$, it was reported that in the region of Umuarama, an area where Caiuá sandstone is predominant and which has low-fertility soils, even rotation systems with a broad crop diversification presented negative final results.

Results may be associated with the fragility of soils in the region, which due to low natural fertility, require greater investment with fertilization and liming to ensure adequate production. This is evidenced by the fact that even with high fertilizer spending, soybean production was almost always below that of the average of Paraná (62 sacks per hectare). In addition, many of the crops selected for winter production had negative profitability and ended up compromising the economic results of production systems. An example of this was the loss generated in winter with crops such as black oats, canola, safflower, crambe, sorghum, buckwheat, and triticale, and the low profit obtained from bean production.

\section{CONCLUSION}

Only the rotation system with the greatest crop diversification (Treatment IV) was profitable, with a positive net farm income. Although, it had the second highest cost of production, it was also the one that generated the highest income, thus showing that this production system's higher cost may be more than offset by its revenue.

The largest revenue was recorded in the most diverse rotation systems, which adopted the largest number of commercial crops both in summer and winter - especially in bean cultivation.

Results obtained in this study indicated that more diversified crop-rotation production systems are more profitable, and this is an important indicator to promote and accelerate the adoption of more sustainable technologies.

Regarding the limitations of the study, it is worth noting that; although, treatments have been devised to obtain the best sequence of plants adapted for the region, this expresses an experimental condition that may not accurately reflect the reality of rural producers. Moreover;, although, the results obtained in three agricultural years are consistent, for a more precise analysis of the profitability of crop rotation systems and the definition of their benefits, it would be appropriate to conduct at least one more cycle of the experiment. In addition, disbursements with machinery operations, recorded as outsourced services, were relatively high, which may have increased production costs, negatively affecting income indicators. However, no remuneration has been computed for the farmer. Production cost estimates made without considering the remuneration of the rural owner (or owners, in the case of commercial partnerships), may reach a value below expectations. It is important to emphasize that the present study does not consider opportunity costs and does not include an economic viability analysis, both important indicators for the producer's decisionmaking and for the management of a rural property. The incorporation of these indicators should be considered in future studies.

\section{ACNOWLEDGEMENTS}

To the Conselho Nacional de Desenvolvimento Científico e Tecnológico $(\mathrm{CNPq})$ for providing financial support [grant number 429050/2016-0]. To the Coordenação de Aperfeiçoamento de Pessoal de Nível Superior (CAPES) for financing part of the study [code 001], and for the scholarship of the first author. To the Fundação Araucária for the scholarship of the third author

\section{DECLARATION OF CONFLICT OF INTERESTS}

The authors declare no conflict of interest. The founding sponsors had no role in the design of the study, in the collection, analyses, or interpretation of data; in the writing of the manuscript, and in the decision to publish the results.

\section{AUTHORS' CONTRIBUTIONS}

The authors contributed equally to the manuscript.

\section{REFERENCES}

AL-KAISI, M. et al. Soybean spatiotemporal yield and economic variability as affected by tillage and crop rotation. Agronomy Journal, v.108, n.3, p.1267-1280, 2016. Available from: <https:// doi.org/10.2134/agronj2015.0363>. Accessed: Nov. 13, 2017. doi: 10.2134/agronj2015.0363

AL-KAISI, M. et al. Tillage and crop rotation effects on corn agronomic response and economic return at seven Iowa locations. Agronomy Journal, v.107, n.4, p.1411-1424, 2015. Available from: < https://doi.org/10.2134/agronj14.0470>. Accessed: Nov. 13, 2017. doi: 10.2134/agronj14.0470.

ARTUZO, F. D. et al. Costs management in maize and soybean production. Revista Brasileira de Gestão de Negócios, v.20, n.2, p.273-294, 2018. Available from: <https://doi.org/10.7819 rbgn.v20i2.3192>. Accessed: Jan. 16, 2018. doi: 10.7819/rbgn. v20i2.3192.

BARBOSA, M. C. et al. Agronomic performance and yield components of soybean cultivars in two sowing dates in the region of Caiuá sandstone. Semina: Ciências Agrárias, v.34, n.3, p.945-960, 2013. Available from: <https://doi.org/10.5433/16790359.2013v34n3p945>. Accessed: Aug. 19, 2018. doi: 10.5433/1679-0359.2013v34n3p945. 
BERTOL, I. et al. Physical soil properties of conventional tillage and no-tillage in crop rotation and succession, compared with natural pasture. Revista Brasileira de Ciência do Solo, v.28, n.1, p.155-163, 2004. Available from: <https://doi.org/10.1590/S010006832004000100015>. Accessed: Sep. 28, 2017. doi: 10.1590/ S0100-06832004000100015.

BORTOLUZZI, E. C. et al. Aggregation of subtropical soil under liming: a study using laser diffraction. Revista Brasileira de Ciência do Solo, v.34, n.3, p.725-734, 2010. Available from: $<$ https://doi.org/10.1590/S0100-06832010000300014>. Accessed: Sep. 28, 2017. doi: 10.1590/S0100-06832010000300014.

BRANCALIÃO, S. R. et al. Grain yield and composition of soybean crop after the supply of nitrgen with use of cover crops at direct sowing. Nucleus, v.12, n.1, p.69-76, 2015. Available from: $<$ https://doi.org/10.3738/1982.2278.1001>. Accessed: Nov. 20, 2018. doi: $10.3738 / 1982.2278 .1001$.

CASTRO, G. S. A. et al. Soil physical properties in crop rotation systems as affected by liming materials. Pesquisa Agropecuária Brasileira, v.46, n.12, p.1690-1698, 2011. Available from: <https:// doi.org/10.1590/S0100-204X2011001200015>. Accessed: Jul. 13, 2017. doi: 10.1590/S0100-204X2011001200015.

CHAVAS, J. P. On the economics of agricultural production. The Australian Journal of Agricultural and Resource Economics, v.52, n.4, p.365-380, 2008. Available from: <https://doi.org/10 1111/j.1467-8489.2008.00442.x>. Accessed: Oct. 05, 2017. doi: $10.1111 / \mathrm{j} .1467-8489.2008 .00442 . \mathrm{x}$

CONAB - Companhia Nacional de Abastecimento. Indicadores da agropecuária. Available from: <http://www.conab.gov.br/>. Accessed: Nov. 15, 2018.

COSTA, A. A. V. M. R. Sustainable agriculture I: Concepts. Revista de Ciências Agrárias, v.33, n.2, p.61-74, 2010. Available from: <https://doi.org/10.19084/rca.15872>. Accessed: Sep. 30, 2017. doi: $10.19084 / \mathrm{rca} .15872$

CUNHA, E. Q. et al. Physical, chemical and biological atributes of soil under organic production as impacted by crop systems. Revista Brasileira de Engenharia Agrícola e Ambiental, v.16, n.1, p.56-63, 2012. Available from: < https://doi.org/10.1590/ S1415-43662012000100008>. Accessed: Feb. 10, 2018. doi: 10.1590/S1415-43662012000100008.

DEBIASI, H. et al. Soybean and corn yield after soil winter covers and soil mechanical loosening. Pesquisa Agropecuária Brasileira, v.45, n.6, p.603-612, 2010. Available from: <https:// doi.org/10.1590/S0100-204X2010000600010>. Accessed: Jun. 12, 2018. doi: 10.1590/S0100-204X2010000600010

DERAL-SEAB- Departamento de Economia Rural da Secretaria da Agricultura e Abastecimento do Paraná. Relatórios de preços. Available from: <http://www.agricultura.pr.gov.br>. Accessed: Mar. 22, 2018.

FIOREZE, S. L. et al. Performance of soybean genotypes under high intensity drought stress in greenhouse conditions. Revista Ceres, v.58, n.3, p.342-349, 2011. Available from: $<$ https://doi. org/10.1590/S0034-737X2011000300015>. Accessed: Mar. 23, 2018. doi: 10.1590/S0034-737X2011000300015.

FONSECA, G. C. et al. Physical, chemical and biological attributes of dystrophic red oxisol under two crop rotations. Pesquisa
Agropecuária Tropical, v.37, n.1, p.22-30, 2007. Available from: $<$ https://www.revistas.ufg.br/pat/article/view/1861>. Accessed: Oct. 11, 2017.

FONTANELI, R. S. et al. Economic analysis of grain production systems with anual winter pastures, under notillage. Pesquisa Agropecuária Brasileira, v.35, n.11, p.21292137, 2000. Available from: <https://doi.org/10.1590/S0100204X2000001100002>. Accessed: Jun. 17, 2018. doi: 10.1590/ S0100-204X2000001100002.

FUENTES-LLANILLO, R. et al. Profitability of no-till grain production systems. Semina: Ciências Agrárias, v.39, n.1, p.77-86, 2018. Available from: <http://dx.doi.org/10.5433/16790359.2018v39n1p77>. Accessed: Mar. 01, 2018. doi: 10.5433/1679-0359.2018v39n1p77.

GAVA, R. et al. Strategies of deficit water management in irrigation of soybean crop. Revista Brasileira de Agricultura Irrigada, v.9, n.6, p.349 - 359, 2015. Available from: <http:// dx.doi.org/10.18011/bioeng2016v10n3p305-315>. Accessed: Jan. 20, 2019. doi: 10.18011/bioeng2016v10n3p305-315.

GENTRY, L. F. et al. Identifying factors controlling the continuous corn yield penalty. Agronomy Journal, v.105, n.2, p.295-303, 2012. Available from: <http://dx.doi.org/10.2134/agronj2012.0246>. Accessed: Jun. 14, 2017. doi: 10.2134/agronj2012.0246.

GERLACH, G.A.X. etal.Economic analysis of bean yield according to nitrogen levels and cover crops. Pesquisa Agropecuária Tropical, v.43, n.1, p.42-49, 2013. Available from: $<$ http://dx.doi. org/10.1590/S1983-40632013000100005>. Accessed: Nov. 05, 2018. doi: 10.1590/S1983-40632013000100005.

GONZÁLEZ, J. et al. Economic evaluation of a crop rotation portfolio for irrigated farms in central Chile. Chilean Journal of Agricultural Research, v.73, n.3, p.243-249, 2013. Available from: <http://dx.doi.org/10.4067/S0718-58392013000300006>. Accessed: Sep. 09,2018. doi: 10.4067/S0718-58392013000300006.

GOPLEN, J. J. et al. Economic performance of crop rotations in the presence of herbicide-resistant giant ragweed. Agronomy Journal, v.110, n.1, p.260-268, 2018. Available from: <http:// dx.doi.org/10.2134/agronj2016.09.0536>. Accessed: Sep. 04, 2019. doi: 10.2134 /agronj2016.09.0536.

GRASSINI, P. et al. Drivers of spatial and temporal variation in soybean yield and irrigation requirements in western US Corn Belt. Field Crops Research, v.163, p.32-46, 2014. Available from: $<$ https://doi.org/10.1016/j.fcr.2014.04.005>. Accessed: Jun. 14, 2017. doi: 10.1016/j.fcr.2014.04.005.

KASSAM, A. et al. The spread of Conservation Agriculture: justification, sustainability and uptake. International Journal of Agricultural Sustainability, v.7, n.4, p.292-320, 2009. Available from: <https://doi.org/10.3763/ijas.2009.0477>. Accessed: Aug. 18, 2017. doi: $10.3763 /$ ijas.2009.0477.

KAY, R. D. et al. Gestão de propriedades rurais. 7ed. Porto Alegre: AMGH, 2014.

KOOCHEKI , A. et al. Effect of cropping systems and crop rotations on weeds. Agronomy for Sustainable Development, v.29, p.401-408, 2009. Available from: <https://doi.org/10.1051/ agro/2008061>. Accessed: Sep. 05, 2019. doi: 10.1051/ agro/2008061. 
LEAL, A. J. F. et al. Economic viability of crops rotation and green manuring preceding the cultivation of no-till system corn in the cerrado. Revista Brasileira de Milho e Sorgo, v.4, n.3, p.298-307, 2005. Available from: $<$ https://doi.org/10.18512/1980-6477/rbms v4n3p298-307>. Accessed: Jul. 04, 2017. doi: 10.18512/19806477/rbms.v4n3p298-307.

LEHMANNA, N. et al. The impact of climate and price risks on agricultural land use and crop management decisions. Land Use Policy, v.35, p.119-130, 2013. Available from: <https://doi. org/10.1016/j.landusepol.2013.05.008>. Accessed: Jan. 31, 2019. doi: 10.1016/j.landusepol.2013.05.008

LISBOA, B. B. et al. Microbial indicators of soil quality in diferente management systems. Revista Brasileira de Ciências do Solo, v.36, p.45-55, 2012. Available from: <https://doi. org/10.1590/S0100-06832012000100004>. Accessed: Oct. 24, 2017. doi: 10.1590/S0100-06832012000100004.

MACHADO, L. A. Z.; ASSIS, P. G. G. Straw and forage production of anual and perennial species in succession to soybean. Pesquisa Agropecuária Brasileira, v.45, n.4, p.415422, 2010. Available from: <https://doi.org/10.1590/S0100204X2010000400010>. Accessed: Nov. 07, 2017. doi: 10.1590/ S0100-204X2010000400010.

MALÉZIEUX, E. et al. Mixing plant species in cropping systems: concepts, tools and models. A review. Agronomy for Sustainable Development, v.29, n.1, p.43-62, 2009. Available from: <https:// doi.org/10.1051/agro:2007057>. Accessed: Jun. 06, 2017. doi: 10.1051/agro:2007057.

MARCELO, A. V. et al. Crop sequences in no-tillage system: I - Dry matter production and nutrient accumulation. Revista Brasileira de Ciência do Solo, v.36, n.5, p.1553-1567, 2012. Available from: $<$ https://doi.org/10.1590/S0100-06832012000500020>. Accessed: Sep. 20, 2017. doi: 10.1590/S0100-06832012000500020.

MCGILL, W. B. et al. Dynamics of soil microbial biomass and water-soluble organic $\mathrm{C}$ in Brenton after 50 years of cropping to two rotations. Canadian Journal of Soil Science, v.66, n.1, p.119, 1986. Available from: <https://doi.org/10.4141/cjss86-001>. Accessed: Sep. 20, 2017. doi: 10.4141/cjss86-001.

NUNES, U. R. et al. Covering crops straw production and common bean productivity in no-tillage system. Pesquisa Agropecuária Brasileira, v.41, n.6, p.943-948, 2006. Available from: <https:// doi.org/10.1590/S0100-204X2006000600007>. Accessed: Aug. 20, 2018. doi: 10.1590/S0100-204X2006000600007.

PERIN, A. et al. Phytomass yield, nutrients accumulation and biological nitrogen fixation by single and associated green manures. Pesquisa Agropecuária Brasileira, v.39, n.1, p.3540, 2004. Available from: <https://doi.org/10.1590/S0100 204X2004000100005>. Accessed: Oct. 30, 2017. doi: 10.1590/ S0100-204X2004000100005

ROLIM, G. S. et al. Spreadshets in EXCEL ${ }^{\mathrm{TM}}$ environment to calculation of water balance: normal, sequencial, culture, and potencial, real produtivity. Revista Brasileira de Agrometeorologia, v.6, n.1, p.133-137, 1998. Available from: <http://sbagro.hospedagemdesites. ws/bibliotecavirtual/arquivos/171.pdf>. Accessed: Nov. 06, 2018.

SANTOS, H. P. et al. Profitability and risk of soil tillage and crop rotation and succession systems. Ciência Rural, v.34, n.1, p.97-103, 2004. Available from: <https://doi.org/10.1590/S0103-
84782004000100015>. Accessed: Jul. 04, 2017. doi: 10.1590/ S0103-84782004000100015.

SANTOS, D. et al. Wheat cultivars submitted to water deficit at the beginning of flowering in greenhouse. Revista Brasileira de Engenharia Agrícola e Ambiental, v.16, n.8, p.836842, 2012. Available from: <https://doi.org/10.1590/S141543662012000800004>. Accessed: Mar. 23, 2018. doi: 10.1590/ S1415-43662012000800004.

SANTOS, H. G. et al. Sistema Brasileiro de Classificação de Solos. Embrapa Solos, 3 ed. Brasília, 2013, 353p.

SANTOS, H. P. et al. Risk analysis of four crop rotation systems for wheat, over a ten-year period, in passo fundo, RS. Pesquisa Agropecuária Brasileira, v.34, n.4, p.519-526, 1999. Available from: <https://doi.org/10.1590/S0100-204X1999000400002>. Accessed: Aug. 03, 2018. doi: 10.1590/S0100-204X1999000400002.

SILVA, J. G.; SENTELHAS, P. C. Difference between screen and grass minimum temperature and probability of its occurrence in nights with frost in the State of Santa Catarina, Brazil. Revista Brasileira de Agrometeorologia, v.9, n.1, p.9-15, 2001. Available from: <http://sbagro.hospedagemdesites.ws/ bibliotecavirtual/arquivos/1260.pdf>. Accessed: Jan. 25, 2019.

SILVA, W. L. et al. Observed trends in climate extreme indicators of temperature and precipitation in the state of Paraná. Revista Brasileira de Meteorologia, v.30, n.2, p.181-194, 2015. Available from: <https://doi.org/10.1590/0102-778620130622>. Accessed: Oct. 25, 2017. doi: 10.1590/0102-778620130622.

TAVARES, L. C. et al. Performance of soybean seeds under water stress: yield and physiological quality of F1 generation. Ciência Rural, v.43, n.8, p.1357-1363, 2013. Available from: $<$ https://doi. org/10.1590/S0103-84782013000800003>. Accessed: Mar. 23, 2018. doi: 10.1590/S0103-84782013000800003.

TELLES, T. S. et al.Conservation agriculture practices adopted in southern Brazil. International Journal of Agricultural Sustainability, v.17, n.5,338-346, 2019. Available from: <https:// doi.org/10.1080/14735903.2019.1655863>. Accessed: Aug. 25, 2019. doi: 10.1080/14735903.2019.1655863.

TILMAN, D. et al. Agricultural sustainability and intensive production practices. Nature, v.418, p.671-677, 2002. Available from: <https://doi.org/10.1038/nature01014>. Accessed: Aug, 20, 2019. doi: 10.1038/nature01014.

VALICHESKI, R.R. et al. Growth of cover crops and soybean yield according to physical attributes in compacted soil. Revista Brasileira de Engenharia Agrícola e Ambiental, v.16, n.9, p.969-977, 2012. Available from: $<$ https://doi.org/10.1590/S1415-43662012000900007>. Accessed: Feb. 01, 2019. doi: 10.1590/S1415-43662012000900007.

VEZZANI, F. M.; MIELNICZUK, J. An overview of soil quality. Revista Brasileira de Ciência do Solo, v.33, n.4, p.743755, 2009. Available from: <https://doi.org/10.1590/S010006832009000400001>. Accessed: Sep. 23, 2017. doi: 10.1590/ S0100-06832009000400001.

VIEIRA, M. J.; MUZILLI, O. Physical characteristics of a dark-red latosol under different soil management. Pesquisa Agropecuária Brasileira, v.19, n.7, p.873-882, 1984. Available from: <http:// seer.sct.embrapa.br/index.php/pab/article/download/15825/9895>. Accessed: Aug. 04, 2018. 